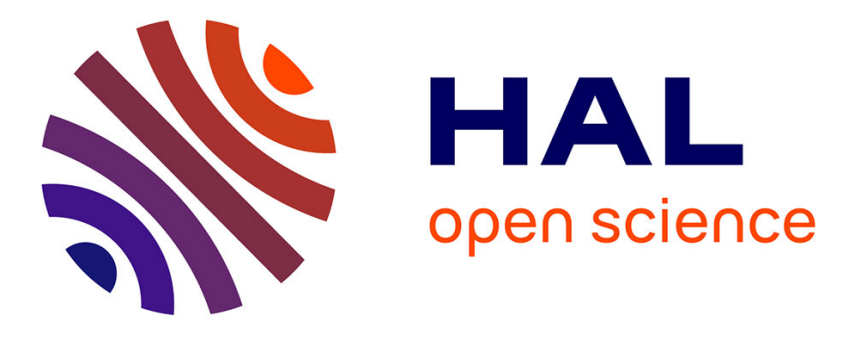

\title{
Ditopic Chelators of Dicopper Centers for Enhanced Tyrosinases Inhibition
}

\author{
Elina Buitrago, Clarisse Faure, Lylia Challali, Elisabetta Bergantino, Ahcène \\ Boumendjel, Luigi Bubacco, Marcello Carotti, Renaud Hardré, Marc Maresca, \\ Christian Philouze, et al.
}

\section{To cite this version:}

Elina Buitrago, Clarisse Faure, Lylia Challali, Elisabetta Bergantino, Ahcène Boumendjel, et al.. Ditopic Chelators of Dicopper Centers for Enhanced Tyrosinases Inhibition. Chemistry - A European Journal, 2021, 27 (13), pp.4384-4393. 10.1002/chem.202004695 . hal-03173336

\section{HAL Id: hal-03173336 https: / hal.univ-grenoble-alpes.fr/hal-03173336}

Submitted on 18 Mar 2021

HAL is a multi-disciplinary open access archive for the deposit and dissemination of scientific research documents, whether they are published or not. The documents may come from teaching and research institutions in France or abroad, or from public or private research centers.
L'archive ouverte pluridisciplinaire HAL, est destinée au dépôt et à la diffusion de documents scientifiques de niveau recherche, publiés ou non, émanant des établissements d'enseignement et de recherche français ou étrangers, des laboratoires publics ou privés. 


\title{
Ditopic Chelators of Dicopper Centers for an Enhancement of Tyrosinases Inhibition.
}

\author{
Elina Buitrago ${ }^{[a, b]}$ Clarisse Faure, ${ }^{[a]}$ Lylia Challali, ${ }^{[a]}$ Elisabetta Bergantino,${ }^{[c]}$ Ahcène Boumendjel, ${ }^{[b]}$ Luigi Bubacco, ${ }^{[c]}$ Marcello Carotti, ${ }^{[c]}$ \\ Renaud Hardré,${ }^{[\mathrm{d}]}$ Marc Maresca, ${ }^{[\mathrm{d}]}$ Christian Philouze,${ }^{[\mathrm{a}]}$ Hélène Jamet, ${ }^{[\mathrm{a}]}$ Marius Réglier, ${ }^{*}{ }^{[\mathrm{d}]}$ and Catherine Belle ${ }^{*[\mathrm{a}]}$
}

\begin{abstract}
Tyrosinase enzymes (Tys) are involved in the key steps of melanin (protective pigments) biosynthesis and molecules targeting the binuclear copper active site on tyrosinases represent a relevant strategy to regulate enzyme activities. In this work, we studied the possible synergic effect generated by combination of known inhibitors. For this, derivatives containing kojic acid (KA) and 2-Hydroxypyridine- $N$-oxide (HOPNO) combined with a thiosemicarbazone (TSC) moiety were synthetized. Their inhibition activities were evaluated on purified tyrosinases from different sources (mushroom, bacterial and human) as well as on melanin production by lysates from human melanoma MNT-1 cell line. Results showed significant enhancement of the inhibitory effects compared to the parent compounds, in particular for HOPNO-TSC. In order to elucidate the interaction mode with the dicopper(II) active site, we investigated the binding studies towards a tyrosinase bio-inspired model of the dicopper(II) center. The structure of the isolated adduct between one ditopic inhibitor (KA-TSC) and the model complex reveals that the binding to a dicopper center can occur with both chelating sites. Computational studies on model complexes and docking studies on enzymes led to the identification of KA and HOPNO moieties as interacting groups with the dicopper active site.
\end{abstract}

[a] Dr. E. Buitrago, C. Faure, L. Challali, Dr. H. Jamet, Dr. C. Philouze, Dr. C. Belle

Université Grenoble Alpes, CNRS, DCM, 38000 Grenoble, France

E-mail: catherine.belle@univ-grenoble-alpes.fr

[b] Prof. A. Boumendjel

Université Grenoble Alpes, CNRS, DPM, 38000 Grenoble, France

[c] Prof. E. Bergantino, Prof. L. Bubacco, Dr. M. Carotti

Department of Biology, University of Padova,

Via Ugo Bassi 58b, 35131 Padova, Italy.

[d] Dr. R. Hardré, Dr. M. Maresca, Dr. M. Réglier

Aix Marseille Université, CNRS, Centrale Marseille, iSm2, Marseille, France.

E-mail: marius.reglier@univ-amu.fr

Supporting information for this article is given via a link at the end of

the document. 


\section{Introduction}

Tyrosinases (Tys, EC 1.14.18.1) belong to type-3 copper enzymes and display three identified dicopper active site states in the catalytic cycle: deoxy $\left(\mathrm{Cu}^{\prime} \mathrm{Cu}^{\prime}\right)$, met $\left(\mathrm{Cu}^{\prime \prime}-\mathrm{Cu}^{\prime \prime}\right)$ and oxy $\left(\mathrm{Cu}^{\prime \prime}-\mathrm{O}_{2}{ }^{2-}-\mathrm{Cu}\right),{ }^{11]}$ as evidenced by X-ray diffraction analysis of Tys from fungi, ${ }^{[2]}$ bacteria, ${ }^{[3]}$ insects ${ }^{[4]}$ or plants. ${ }^{[5]}$ There is to date only one recently resolved X-ray structure of an associated tyrosinase enzyme for human Tyrosinase available (tyrosinase-related proteins-TRP1). ${ }^{[6]}$ TRP1 contains a dinuclear zinc site (in place of the expected di-copper site) ${ }^{[7]}$ but displays the typical tyrosinase folding. The active site is highly conserved in all Tys, and is composed of two copper atoms coordinated by three histidine residues. In the met form, one or two bridged oxygen atoms from aquo (hydroxido) ligands provide an antiferromagnetic coupling between the $\mathrm{Cu}^{\text {II }}$ ions, which is the characteristic of type 3 copper enzymes. ${ }^{[1]}$ In all organisms, Tys are involved in the biosynthesis of protective melanin type pigments. Using molecular oxygen Tyrosinases catalyze hydroxylation of monophenols to respective $o$-quinones by a four electrons process (monooxygenase activity) as well as oxidation of $o$ diphenols substrates to o-quinones (catecholase or diphenolase activity)(Scheme 1) ${ }^{[8]}$ In plants, Tys are responsible for the browning of fruits and vegetable (such as banana, apple, avocado), ${ }_{1}{ }^{9]}$ which is an important issue problem for the food industry with negative economic repercussions. Hence, the development of Ty inhibitors to control these browning processes represents important economic and industrial impacts. ${ }^{[9 b, 10]}$ In mammals, the biological function of these enzymes is to convert L-tyrosine into L-dopaquinone (Scheme 1), which is the key product in the melanin (photo protective pigment) biosynthesis. Melanin-related disorders are known to cause hyperpigmentation ${ }^{[11]}$ and serious skin lesions. ${ }^{[12]}$ Moreover, several studies have reported possible links to Parkinson's disease ${ }^{[13]}$ and melanoma. ${ }^{[14]}$ As Ty inhibition is a well-established approach for controlling melanin production, development of Ty inhibitors raises a considerable interest for cosmetic industries. ${ }^{[15]}$

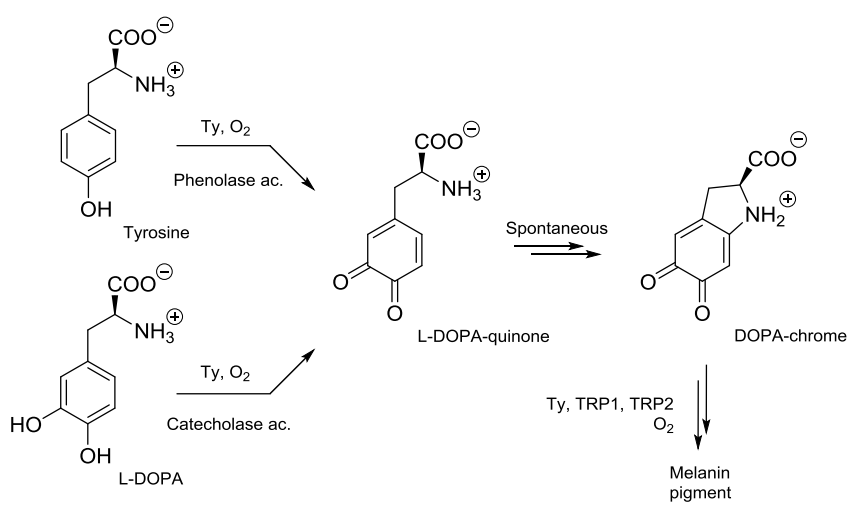

Scheme 1. Reactions catalyzed by mammal tyrosinases. TRP1 and TRP2 are tyrosinase related protein 1 and 2. Inspired from reference $8 \mathrm{c}$

Despite the large number of in vitro Ty inhibitors described in the literature, only few were relevant in clinical trials $^{[14]}$ or in industrial applications. ${ }^{[1 b]}$ Many available Ty inhibitors suffer from toxicity and/or lack of efficacy (only few inhibitors with high inhibition potency, ie $\mathrm{IC}_{50}<10 \mu \mathrm{M}$ ). Therefore, the development of efficient Ty inhibitors continues to receive considerable attention as reported in recent reviews. ${ }^{[16]}$ Molecules targeting the binuclear copper active site through competitive inhibition represent a relevant strategy to achieve specificity and efficient Ty inhibition. ${ }^{[12 b]}$ Metal chelators such as thiosemicarbazones, kojic acid (KA, 5-hydroxy-2(hydroxymethyl)-4-pyrone) or substituted pyridine- $N$ oxide (Scheme 2) are a good illustration of this strategy. We have previously studied interactions of phenylmethylene thiosemicarbazone (PTSC), ${ }^{[17]}$ and 2-hydroxypyridine- $N$-oxide (HOPNO) ${ }^{[18]}$ with dicopper centers by combining studies on functional models and enzymes. Furthermore, derivatives of KA have been extensively explored to provide efficient Ty inhibitors. ${ }^{[19]}$

In a previous study using KA-TSC, which is a conjugation of KA with a thiosemicarbazone moiety (TSC), we observed a 9-fold enhancement of the inhibition of diphenolase activity on the Agaricus bisporus Ty compared to KA alone (TyAb, Table 1, entry 1) ${ }^{[20]}$ Additionally, several reports on catechol-like inhibitors (KA and HOPNO) mention that some of them act as mixed inhibitors. ${ }^{[1]}$ This suggests the presence of two different binding sites for these inhibitors: 1) a KA/HOPNO binding in the active site which competes with the substrate (for KA this is experimentally supported by Electron spin echo envelope modulation (ESEEM) ${ }^{[22]}$, X-ray absorption spectroscopy $(X A S)^{[23]}$ and paramagnetic NMR studies on bacterial Streptomyces antibioticus ${ }^{[24]}$ ) and 2) another site which does not affect the binding of the substrate but inhibits the enzymatic reaction. These propositions were recently confirmed by the Fishman group, ${ }^{[3 a, 21 d]}$ who has resolved the crystal structures of the Bacillus megaterium Ty $(\mathrm{TyBm})$ in complex with $\mathrm{KA}$. In one of these structures, $\mathrm{KA}$ is observed at the entrance to the active site with its hydroxy group opposite to the center of the copper at a distance of approximately $13 \AA$ (Figure 1$)^{[3 a]}$ while in a second structure, KA is observed inside the active site with its hydroxyl group oriented towards the copper center at a distance of 3.3 and $3.5 \AA$ from CuA and CuB, respectively (Figure 1). ${ }^{[21 d]}$ Similar position of KA has been previously proposed from in silico simulations on $\mathrm{TyAb}^{[25]}$ and TySa. ${ }^{[26]}$ 


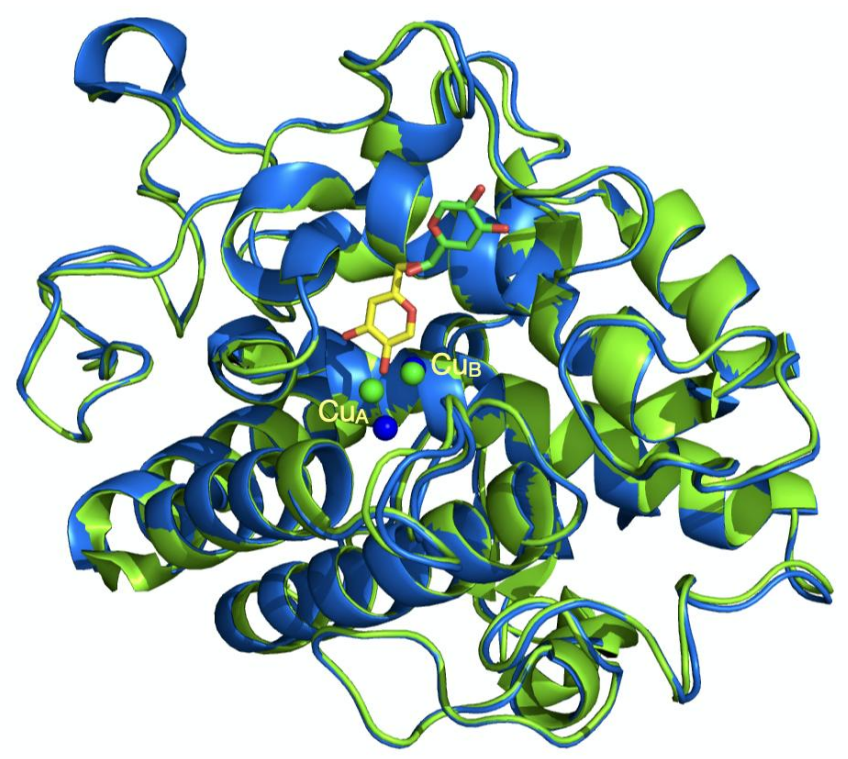

Figure 1. 3D structures of KA bound to Ty from B. megaterium: $(A)$ in one structure (pdb: $5 i 38$ ) $K A$ (in yellow) is observed inside the active site with its hydroxyl group oriented towards $\mathrm{CuA}$ at a distance of $3.3 A_{;}^{[3 a]}(B)$ in another structure (pdb: 3nq1) KA (in green) is observed at the entrance to the active site. ${ }^{[21 d]}$

These results demonstrate the benefit of developing ditopic inhibitors capable of occupying the two sites. Moreover, in our previous studies, we observed that the combination of a thiosemicarbazone moiety (TSC) with KA resulted in a decrease of the $\mathrm{IC}_{50}$ value in the inhibition of diphenolase activity on the Agaricus bisporus Ty compared to the parent TSC and KA compounds. ${ }^{[20]}$ Inspired by the above progress, herein we propose the synthesis of new inhibitors combining TSC, KA and HOPNO motives such as in KA-TSC and HOPNO-TSC compounds (Scheme 2). In order to check the chelating effect of the HOPNO motive in HOPNO-TSC, we also synthetized and evaluated hybrids containing a TSC motive combined to a pyridine oxide moiety such as in 3PyNO-TSC and 4PyNO-TSC (Scheme 2). Through the proposal of these new scaffolds, our ultimate objective is the development of more selective and potent inhibitors for Tys.

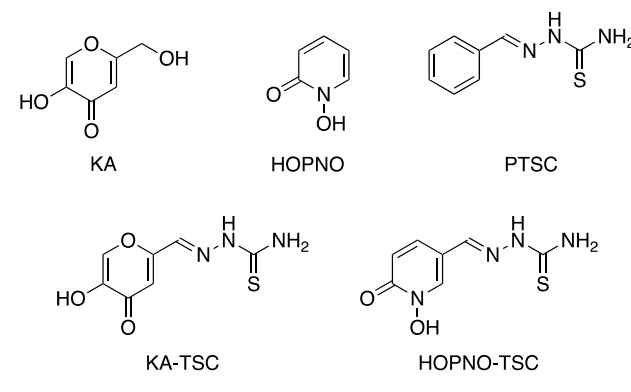<smiles></smiles>

Scheme 2. Structure of molecules studied in this work

Furthermore, it is now demonstrated ${ }^{[21 c, 27]}$ that the environment in the second coordination spheres between Tys from different sources is different, and that the extrapolation of the inhibition activity from one source to the others is hazardous. The low level of sequence homology between tyrosinases and differences in the binding pocket topologies reported by different authors ${ }^{[2 a, 2 b, 3,27-28]}$ lead us to perform comparative inhibition studies on purified tyrosinases from different sources: recombinant human Homo sapiens (TyHs), bacterial from Streptomyces antibioticus (TySa) and fungal from Agaricus bisporus (TyAb), to get more information about the tested compounds and their respective capacity to inhibit the enzymes. Finally, the evaluation of their effect on melanin production in human MNT-1 melanoma cell lines has been performed. 


\section{Results and Discussion}

\section{Synthesis of target compounds}

The $\mathrm{N}$-oxides containing thiosemicarbazones were efficiently synthesized in 3 steps starting from the corresponding pyridine aldehydes (Scheme 3). The aldehyde function was protected as a methyl acetal to avoid oxidation into carboxylic acid, and the oxidation of the pyridines was then carried out using mCPBA in the presence of sodium bicarbonate. The protected pyridine aldehydes were isolated with good yields after purification. The methyl acetal was then removed under acidic conditions and the corresponding aldehyde reacted with thiosemicarbazide in one pot to give the pyridine $\mathrm{N}$-oxide thiosemicarbazones. The hydroxyl protecting methyl group in HOPNO was also removed during this step to yield HOPNO-TSC. The synthesis of KA-TSC was performed as previously described by us. ${ }^{[20]}$

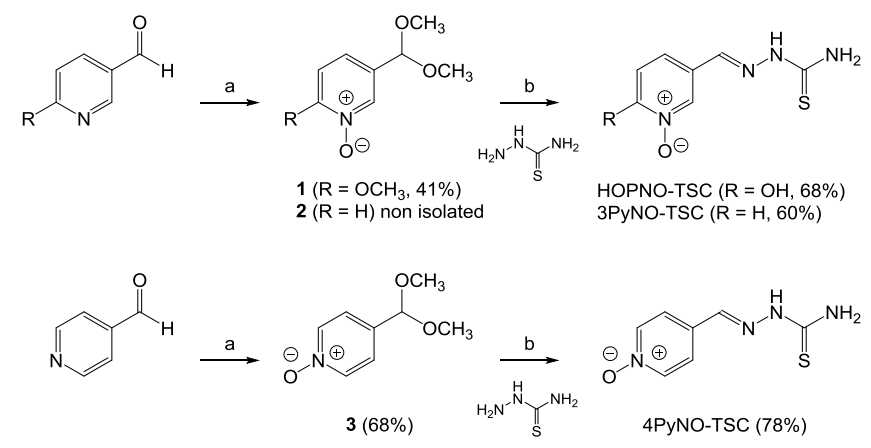

Scheme 3. Synthesis of HOPNO-TSC, 3PyNO-TSC and 4PyNO-TSC: a) $\mathrm{CH}_{2}\left(\mathrm{OCH}_{3}\right)_{2}, p \mathrm{TSA}, \mathrm{MeOH}$ then $m \mathrm{CPBA}, \mathrm{NaHCO}_{3}, \mathrm{CHCl}_{3}$; b) $\mathrm{HCl}$, $\mathrm{EtOH}$.

\section{Enzymatic assay for inhibitory activity}

To evaluate the efficiency of the new ditopic chelators as tyrosinase inhibitors, we assayed the enzyme diphenolase activity, i.e. the oxidation of L-DOPA to DOPAchrome, by UV-vis. The activities of the new hybrid compounds were then compared to those of the parent compounds (KA, HOPNO and PTSC).

The $\mathrm{IC}_{50}$ values were first determined at L-DOPA concentrations around $0.1 \mathrm{mM}$ as a first screening on TyAb and TySa (Figures S1-2). The results are summarized in Table 1. While the parent compounds KA, HOPNO and PTSC exhibit IC 50 values in a large range of 2 to $100 \mu \mathrm{M}$ (Table 1, entries 1-3), the corresponding hybrid compounds KA-TSC (Table 1, entry 4) and HOPNO-TSC (Table 1, entry 5) are better inhibitors with $\mathrm{IC}_{50}$ in the range of 1 to $10 \mu \mathrm{M}$. With a sub-micromolar $\mathrm{IC}_{50}$, the most important synergetic effect is observed for the TyAb inhibition by HOPNO-TSC $(0.56 \mu \mathrm{M})$. Conversely, the hybrid compounds 3PyNO-TSC and 4PyNO-TSC proved to be equivalent for TySa or even less potent for TyAb of the parent compound PTSC (Table 1, entries 6 and 7).

Table 1. Inhibition activity using L-DOPA as a substrate for S. antibioticus Ty (TySa) in comparison to A. bisporus Ty (TyAb).

\begin{tabular}{llcc}
\hline \multirow{2}{*}{ Entries } & Compounds & \multicolumn{2}{c}{$\mathrm{IC}_{50}(\mu \mathrm{M})$} \\
& & TySa & TyAb \\
\hline 1 & KA & $\sim 3.4^{\mathrm{a}}$ & $102^{[20]}$ \\
2 & HOPNO & $6.4 \pm 1.1^{[29]}$ & $1.2^{[18]}$ \\
3 & PTSC & $24 \pm 2^{\mathrm{b}}$ & $7.5 \pm 0.5^{[17]}$ \\
4 & KA-TSC & $1.6 \pm 0.2^{\mathrm{c}}$ & $9.6 \pm 0.8^{\mathrm{c}}$ \\
5 & HOPNO-TSC & $2.0 \pm 0.5^{\mathrm{b}}$ & $0.56 \pm 0.03^{\mathrm{b}}$ \\
6 & 4PyNO-TSC & $10 \pm 2^{\mathrm{c}}$ & $18 \pm 2^{\mathrm{b}}$ \\
7 & 3PyNO-TSC & $24 \pm 5^{\mathrm{c}}$ & $60 \pm 3^{\mathrm{b}}$ \\
\hline
\end{tabular}

a): estimated from $K_{1}$ reported in reference 23 ; b) this work: L-DOPA] $=0.1 \mathrm{mM}$ and c) this work: $\left.L-D O P A\right]=0.15 \mathrm{mM}$

The kinetic behavior of these compounds was then studied on mushroom, bacterial and human Ty-catalyzed oxidation of L-DOPA. We determined the Michaelis-Menten kinetic parameters $\left(K_{M}\right.$ and $\left.V_{\max }\right)$ for L-DOPA oxidation for the three enzymes by plotting the initial rate of DOPAchrome formation versus the concentration of L-DOPA. This gave us $K_{\mathrm{M}}=0.21 \pm 0.04 \mathrm{mM}$ and $V_{\max }=0.239 \pm 0.008 \mathrm{mMs}^{-1}$ for TyAb (Figure S5), $K_{\mathrm{M}}=0.54 \pm 0.7 \mathrm{mM}$ and $V_{\max }=0.36 \pm$ $0.01 \mathrm{mMs}^{-1}$ for TySa (Figure S10) and $K_{\mathrm{M}}=0.27 \pm 0.03 \mathrm{mM}$ and $V_{\max }=0.343 \pm 0.008 \mathrm{mMs}^{-1}$ for TyHs (Figure S16). 
For various concentrations of inhibitors, the initial rates were determined at various L-DOPA concentrations. From Lineweaver Burk plots, a set of $1 / V_{\max }{ }^{\text {app }}$ and $K_{\mathrm{M}}{ }^{\text {app }} / V_{\max }{ }^{\text {app }}$ were used for the determination of the inhibition constants $K_{\mathrm{I}}$ (eqs. 1 and 2).

$\begin{array}{ll}1 / V_{\max }^{\text {app }}=\left(1 / V_{\max }\right)\left(1+[I] / K_{I U}\right) & \text { eq. } 1 \\ K_{M}^{\text {app }} / V_{\max }^{\text {app }}=\left(K_{M} / V_{\max }\right)\left(1+[I] / K_{I C}\right) & \text { eq. } 2\end{array}$

where, $[I]$ is the inhibitor concentration, $K_{\mathrm{IU}}$ is the uncompetitive constant of inhibition and $K_{\mathrm{IC}}$ the competitive one. The inhibition constants $K_{\mathrm{IU}}$ and $K_{\mathrm{IC}}$ were determined from eq. 1 and 2, respectively. According to eq. 1, the linear regression of the $1 / V_{\max }{ }^{\text {app }} v s$. [l] plot leads to the $K_{\mathrm{IU}}$ constant. The same treatment according to eq 2 , the $K_{\mathrm{M}}{ }^{\text {app }} / V_{\max }{ }^{\text {app }} v s$. [I] plot leads to the $K_{\mathrm{IC}}$ constant (Supplementary material). When $K_{\mathrm{IU}}>>K_{\mathrm{IC}}$, the inhibitor is considered as competitive (C), $K_{\mathrm{IU}}$ $\ll K_{\mathrm{IC}}$ as uncompetitive $(\mathrm{UC})$ and $K_{\mathrm{IU}} \sim K_{\mathrm{IC}}$ as non-competitive $(\mathrm{nC})$. The inhibition constants are summarized in Table 2.

The first analysis of the kinetic data reported in Table 2 shows that the conjugation of TSC with 3PyNO and 4PyNO does not significantly the performances of PTSC (for TyAb, $K_{1}^{\text {PTSC }}=0.93 \mu \mathrm{M} v s$. $K_{1}^{3 P y N O-P T S C}=69 \mu \mathrm{M}$ and $K_{1}^{4 P y N O-P T S C}=$ $58 \mu \mathrm{M})$. In the better case, for TySa, the performances of 3PyNO-TSC and 4PyNO-TSC are in the same range that of PTSC $\left(K_{l}^{\text {PTSC }}=19 \mu \mathrm{M}\right.$ vs. $K_{l}^{\text {3PyNO-PTSC }}=13 \mu \mathrm{M}$ and $\left.K_{l}^{\text {4PyNO-PTSC }}=7 \mu \mathrm{M}\right)$. For the TyAb, 3PyNO-TSC and 4PyNO-TSC exhibit the worst performances with $K_{\mathrm{l}}=3.1 \mathrm{mM}$ and $1.8 \mathrm{mM}$, respectively.

On TySa, the conjugated KA-TSC derivative performs better that KA and PTSC individually $\left(K_{1}^{\mathrm{KA}-\mathrm{TSC}}=1.4 \mu \mathrm{M}\right.$ with $K_{1}^{\mathrm{KA}} / K_{1}^{\mathrm{KA}-\mathrm{TSC}}=2.4$ and $\left.K_{1}^{\mathrm{PTSC}} / K_{1}^{\mathrm{KA}-\mathrm{TSC}}=14\right)$. For TyHs instead, with constants in the same range, the conjugation does not improve the performances of KA $\left(K_{1}^{\mathrm{KA} \text {-TSC }}=260 \mu \mathrm{M}\right.$ with $\left.K_{l}^{\mathrm{KA}} / K_{l}^{\mathrm{KA}-\mathrm{TSC}}=1.3\right)$. The effect of the conjugation is less pronounced for TyAb as the constant $K_{1}^{\mathrm{KA}-\mathrm{TSC}}$ is lower $\left(K_{1}^{\mathrm{KA}} / K_{1}^{\mathrm{KA}-\mathrm{TSC}}=3.1\right)$ for the parent $\mathrm{KA}$ but higher for PTSC $\left(K_{1}^{\mathrm{KA}-\mathrm{TSC}}\right.$ $=7.2 \mu \mathrm{M}$ with and $\left.K_{1}^{\mathrm{PTSC}} / K_{1}^{\mathrm{KA}-\mathrm{TSC}}=0.1\right)$. In this later case, there is no benefit from the conjugation.

The most important enhancement of the inhibitory effect observed among the ditopic molecules presented here was measured with HOPNO-TSC. The $K_{1}$ value of HOPNO-TSC is several folds lower than those of the parent compounds PTSC and HOPNO (Table 2, entry 5). With sub-micromolar $K_{1}$ for TyAb and TySa, the $K_{1}^{\text {HOPNO }} / K_{1}^{\text {HOPNO-TSC }}$ ratio is $>2$ and 9 , respectively. For TyHs the value of $K \mathrm{l}$ is quite high $(47 \mathrm{mM})$, however, the $K_{1}^{\text {HOPNO}} / K_{1}^{\text {HOPNO-TSC }}$ ratio of 2.7 is in the same order of magnitude as for the other Ty sources. The kinetic study of HOPNO-TSC inhibition shows that they behave as a competitive inhibitor for TyAb and TySa and a mixed inhibitor for TyHs but with a quite high competitive contribution $\left(K_{\mathrm{IU}} / K_{\mathrm{IC}}>19\right)$.

Table 2. Comparison of the kinetic inhibition constants $K_{\mathrm{I}}(\mu \mathrm{M})$ obtained for tyrosinases of different sources, Agaricus bisporus (TyAb), Streptomyces antibioticus (TySa) and Homo sapiens (TyHs). C; competitive inhibition and nC, non-competitive inhibition. (n.a.: not applicable)

\begin{tabular}{|c|c|c|c|}
\hline \multirow{2}{*}{ Inhibitors } & \multicolumn{3}{|c|}{$K_{\mathrm{l}}$ in $\mu \mathrm{M}$ (inhibition mode) } \\
\hline & TyAb & TySa & TyHs \\
\hline KA & $22.3(C)^{[30]}$ & $3.4 \pm 0.3(C)^{[24]}$ & $\begin{array}{c}K_{\mathrm{IC}}=350 \pm 70 \\
K_{\mathrm{IU}}=730 \pm 190^{[2 \mathrm{cc}]}\end{array}$ \\
\hline HOPNO & $1.8(\mathrm{C})^{[18]}$ & $7.7 \pm 0.2(C)^{[29]}$ & $128 \pm 2(\mathrm{C})^{[31]}$ \\
\hline PTSC & $0.93 \pm 0.1(C)^{[17]}$ & $\begin{array}{l}K_{\mathrm{IC}}=19 \pm 2 \\
K_{\mathrm{lU}}=30 \pm 9\end{array}$ & n.a. \\
\hline KA-TSC & $7.2 \pm 0.4(\mathrm{C})$ & $1.4 \pm 0.40(C)$ & $260 \pm 20(n C)$ \\
\hline HOPNO-TSC & $0.5 \pm 0.1(\mathrm{C})$ & $0.82 \pm 0.9(\mathrm{C})$ & $47 \pm 1(\mathrm{C})$ \\
\hline 4PyNO-TSC & $\begin{array}{c}K_{\mathrm{IC}}=58 \pm 14 \\
K_{\mathrm{IU}}=98 \pm 22\end{array}$ & $7 \pm 2(\mathrm{C})$ & $1800 \pm 200(\mathrm{nC})$ \\
\hline 3PyNO-TSC & $\begin{array}{c}K_{\mathrm{IC}}=69 \pm 9 \\
K_{\mathrm{IU}}=108 \pm 34\end{array}$ & $13 \pm 3(C)$ & $3100 \pm 200(n C)$ \\
\hline
\end{tabular}




\section{Melanin biosynthesis inhibition}

The KA-TSC and HOPNO-TSC hybrid compounds were evaluated and compared to their KA and HOPNO parent compounds as inhibitors of melanin biosynthesis in lysates of the human cellular model (human melanoma MNT-1 cells). This evaluation confirms the tendency observed with the purified enzyme, ie: HOPNO-TSC > HOPNO > KA-TSC or KA (Figure 2). With an $\mathrm{IC}_{50}$ of $0.56 \mathrm{mM}$, the HOPNO-TSC hybrid compound confirmed its capacity to prevent melanogenesis in complex cytoplasmic environment of human cells. As for the purified enzyme (TyHs), the contribution of the TSC moiety is significant on MNT-1 lysates, HOPNO alone remains 2-fold less active than HOPNO-TSC $\left(\mathrm{IC}_{50}=1.14\right.$ vs. 0.56 $\mathrm{mM}$, respectively). On the contrary, introduction of the TSC moiety toward KA-TSC decreases the inhibition on the melanin biosynthesis more than 3-fold compared to $\mathrm{KA}\left(\mathrm{IC}_{50}=8.63 \mathrm{vs} .2 .28 \mathrm{mM}\right.$, respectively). This difference observed between the purified enzyme TyHs and MNT-1 lysate is probably due to the presence of other enzymes in MNT-1 (TRP1, TRP2 or others) involved in the melanin biosynthesis that could also be targets of melanin effectors. This result points out the importance of verifying the activities of Ty inhibitors on the lysates of MNT-1 cells to be sure to have efficient melanin biosynthesis inhibitors.

The observed inhibition behaviors for the hybrid compounds on isolated tyrosinases are largely competitive, evidencing interactions at the active site. So to gain more information on fixation mode (hybrid inhibitors display two chemical groups potentially able to interact with copper atoms), we decided to use a model complex of the active site to study the positioning of the inhibitors in the active site in detail.

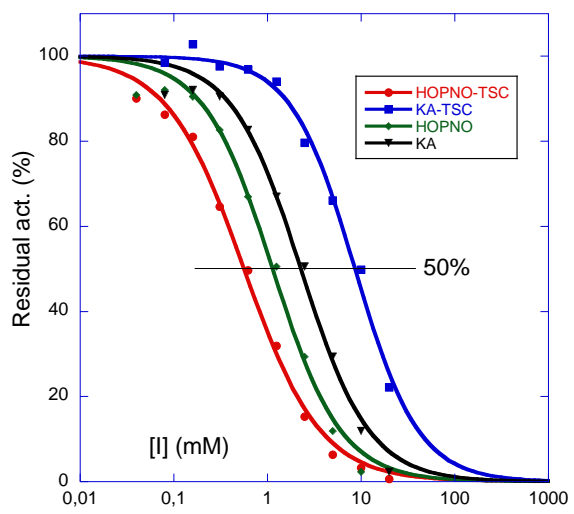

Figure 2. Dose-dependent effects of tyrosinase inhibitors on MNT-1 lysates. HOPNO-TSC $\left(\mathrm{IC}_{50}=0.56 \pm 0.03 \mathrm{mM}\right), \mathrm{KA}-\mathrm{TSC}\left(\mathrm{IC} \mathrm{C}_{50}=8.63 \pm 0.48\right.$ $\mathrm{mM})$, HOPNO $\left(\mathrm{IC}_{50}=1.14 \pm 0.08 \mathrm{mM}\right)$ and kojic acid $\left(\mathrm{KA}, \mathrm{IC}_{50}=2.28 \pm 0.17 \mathrm{mM}\right)$

\section{Studies on model}

We have previously studied the binding interactions of the parent compounds PTSC, ${ }^{[17]} \mathrm{KA}^{[26]}$ and HOPNO ${ }^{[18]}$ with a binuclear copper(II) complex (4), ${ }^{[32]}$ model of the Ty active site (Scheme 4).

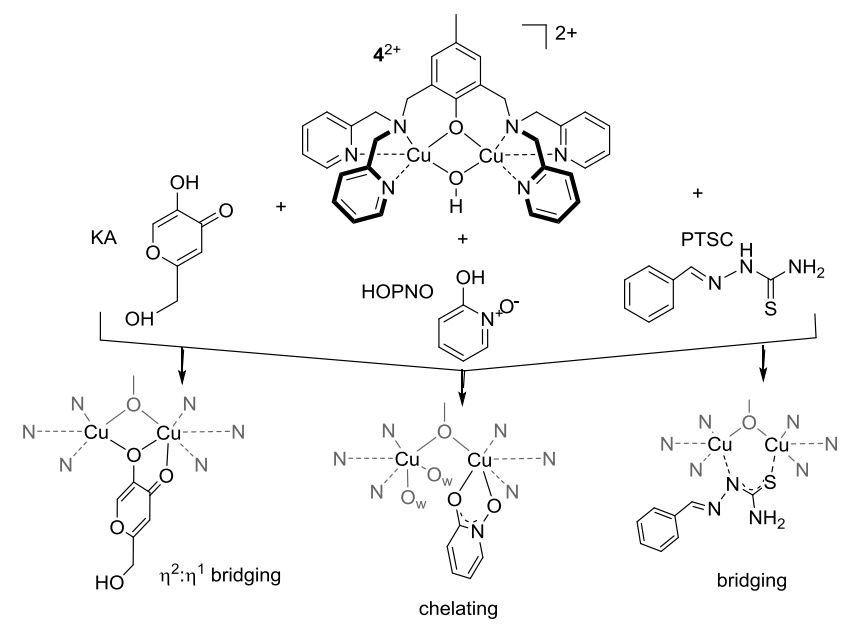

Scheme 4. Isolated and X-ray characterized adducts of kojic acid $(\mathrm{KA}),{ }^{[26]}$ 2-hydroxypyridine- $\mathrm{N}$-oxide $(\mathrm{HOPNO})^{[18]}$ and phenylmethylene thiosemicarbazone (PTSC) ${ }^{[17]}$ with the model complex $4^{2+}$ 
Following the rationale proposed in our previous studies, we carried out investigations on the molecular interactions of model complex 4 (scheme 4) and the new inhibitors KA-TSC and HOPNO-TSC. Reaction of complex 4 with KA-TSC ( 1:4 ratio) in methanol and slow vapor diffusion of diethyl ether afforded a small amount of brown/red single crystals after one week. Crystallographic analysis validated the presence of an adduct between 4 and KA-TSC with $2: 1$ stoichiometry. The unit cell contains two crystallographically independent $\left[\left(\mathrm{Cu}_{2}(\mathrm{BPMP})\right)_{2}(\mathrm{KA}-\right.$ TSC)](OTf) 4 - solvate entities (5), where $\mathrm{OTf}^{-}=\mathrm{CF}_{3} \mathrm{SO}_{3}{ }^{-}$and the solvates stand for methanol, diethyl ether and $\mathrm{H}_{2} \mathrm{O}$. Each cationic unit, one of which $\left(5 \mathrm{~A}^{4+}\right)$ is shown in Figure $3\left(5 \mathrm{~B}^{4+}\right.$ in Supporting Information, Figure S21), consists of two dinuclear complexes $\mathrm{Cu}_{2}$ (BPMP) bridged by a doubling deprotonated KA-TSC entity coordinated on two sides replacing the $\mu$-hydroxido ligand in 4. Selected bond distances and angles are reported in Table (S15-16) and show no significant differences between the observed coordination modes of the parent complexes $4-\mathrm{KA}^{[26]}$ and $4-\mathrm{PTSC}{ }^{[17]}$ (Scheme 4) as evidenced by the superposition of the respective structures with $5 \mathrm{~A}^{4+}$ (Figure S22). The bridging mono-deprotonated TSC increases the Cu...Cu distance from approximately $\sim 2.9 \AA$ in complex 4 to $3.339 \AA$ in $5 \mathrm{~A}$ (3.374 $\AA$ in $5 \mathrm{~B}$ ), and to $3.163 \AA$ in $5 \mathrm{~A}(3.178 \AA$ in $5 \mathrm{~B})$ on the side of $\mathrm{KA}$.

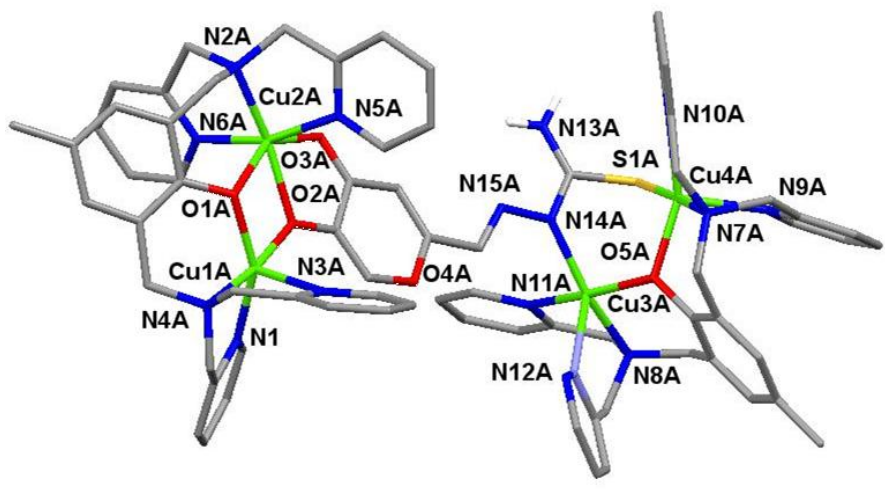

Figure 3. Molecular structure of $\mathbf{5} \mathbf{A}^{4+}$. Hydrogen atoms (except the one linked to the nitrogen of TSC group), counterions and solvent molecules have been omitted for clarity). Selected bond lengths $[\AA]$ and angles $\left[^{\circ}\right]$ are in the ESI (Table S15-16).

The coordination polyhedron around the Cu1A atom is a distorted square pyramid whose apical position is occupied by the pyridine nitrogen N3A. The coordination environment around Cu2A forms a distorted octahedral geometry with nitrogen N2A of the tertiary amine, two pyridine nitrogen N5A and N6A of the ligand and the oxygen O2A from the KA moiety in equatorial position. On the contrary, binding of the TSC group leads to a distorted square pyramidal geometry for Cu3A and Cu4A atoms whose apical positions are occupied by pyridine nitrogen N9A and N12A. The ESI-MS spectrum of isolated adduct 5 in methanol provides a fragment at $\mathrm{m} / \mathrm{z}=1016\left(z=1,\left[\mathrm{Cu}_{2}(\mathrm{BPMP})(\mathrm{KA}-\right.\right.$ $\mathrm{TSC})](\mathrm{OTf})^{+}$corresponding to a $1: 1$ adduct of KA-TSC and complex 4 (Figures S23-24) with observed/theoretical isotopic pattern distribution) indicating easy dissociation of $\mathbf{5}$ in solution.

Reaction of complex 4 with HOPNO-TSC did not allow the isolation of any adduct. The ESI-MS spectrum of 4 (1 equiv.) dissolved in MeOH:DMSO (3:1) with HOPNO-TSC (3.5 equiv.) give a fragment at 433 ( $z=2$, $\left[\mathrm{Cu}_{2} \text { (BPMP)(OPNO-TSC) }\right]^{2+}$ ) (Figure S25) with observed/theoretical isotopic pattern distribution) corresponding to the dicharged ion of $\left[\mathrm{Cu}_{2}(\mathrm{BPMP})(\mathrm{OPNO}-\mathrm{TSC})\right] \cdot(\mathrm{OTf})_{2}$ providing evidence that an 1:1 adduct between 4 and HOPNO-TSC is present in methanol solution as similarly observed for 5 (see above).

The UV/Vis spectrum of complex 4 shows a characteristic ligand to metal CT band from the copper bridging phenoxido ligand at $410 \mathrm{~nm}\left(\varepsilon=295 \mathrm{M}^{-1} \mathrm{~cm}^{-1}\right)$ and a d-d transition at $730 \mathrm{~nm}\left(\varepsilon=230 \mathrm{M}^{-1} \mathrm{~cm}^{-1}\right)$. By adding the inhibitors to a solution of complex 4 and analyzing the changes in the absorption bands, namely, an increase of absorption in the $\mathrm{d}-\mathrm{d}$ transition band and a decrease in the LMCT band, we were able to determine the binding constants using the Specfit program. ${ }^{[33]}$ The best refinements of the absorbance data versus inhibitor concentration give a binding constants in the same range as for PTSC $\left(K_{\mathrm{b}}=105-106 \mathrm{M}^{-1}\right){ }^{[17]}$ which indicate weak interactions with the dicopper center in 4. By comparison, both ditopic compounds display high affinity for Ty enzymes (Table 2). Considering the X-ray structure of $\mathbf{5}$ (Figure 3), it evidences that KA-TSC is able to bind a dicopper center by the hydro ketone group as well as by the thiosemicarbazone group. Furthermore, both ditopic inhibitors display a competitive mode toward tyrosinases (Table 2) (except a non-competitive behavior for KA-TSC on TyHs) indicating that these compounds interact with the binuclear copper active site of the enzymes. Furthermore, the different inhibitory potency of HOPNO-TSC and KA-TSC compared 
to the parent compounds suggest second-sphere interactions with the amino acid residues in the proximity of the active site of the enzymes. Altogether, information from computational studies should help to discriminate the group oriented towards the copper active site for KA-TSC and HOPNO-TSC as well as the possible interactions with the second coordination sphere.

\section{Computational studies}

We first investigated the model complex $4^{2+.}$ We consider KA-TSC and HOPNO-TSC, deprotonated on each group of the molecule (KA and TSC for the first inhibitor, HOPNO and TSC for the second) and two binding modes, one mode in which the TSC part of the molecule interacts with the two copper atoms and one mode in which the other part of the molecule is bound. To construct these complexes, we used X-ray characterized adducts of kojic acid (KA), ${ }^{[26]} 2$ hydroxypyridine-N-oxide (HOPNO) ${ }^{[18]}$ and phenylmethylene thiosemicarbazone (PTSC) ${ }^{[17]}$ with model complex $4^{2+}$ (Scheme 4) as starting points. Figure 4 shows the different structures obtained after geometry optimizations. To compare the binding mode, their free energies were computed. For the two inhibitors, the binding mode in which the TSC part was not coordinating the metal ions was found to be favorable by $24.9 \mathrm{kcal} / \mathrm{mol}$ for KA-TSC and $13.1 \mathrm{kcal} / \mathrm{mol}$ for HOPNO-TSC.

A
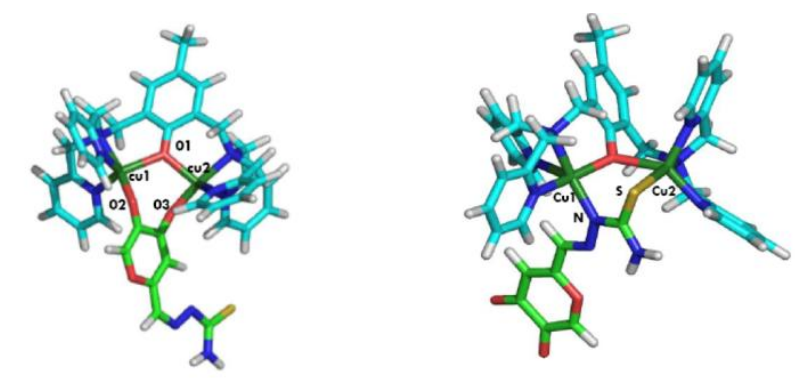

B
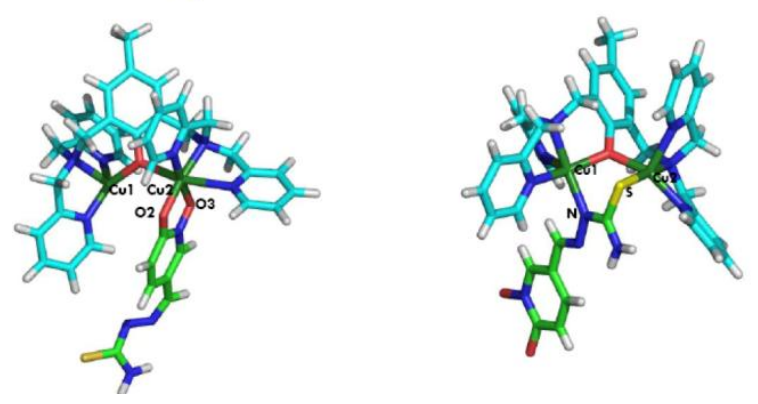

Figure 4. The different binding modes for complex 4 with KA-TSC (A) and HOPNO-TSC (B) after geometric optimizations. Atoms from the inhibitors are represented in green (carbon atoms), in blue (nitrogen atoms), in yellow (sulfur atoms), in red (oxygen atoms) and copper atoms are in dark green.

Similar studies were done on the three enzymes (TyAb, TyHs and TySa) and docking studies were performed using the Autodock 4.0 software. ${ }^{[34]}$ The choices used (structures and forms) are explained in the experimental computational part. With the docking procedure, different positions were generated (see experimental computational part). Results close in positional root-mean-square deviation (RMSD) were clustered together and ranked in a histogram according to their binding free energies. For all tyrosinases, the most populous clusters obtained were always the lowest energy cluster, with a high number of conformers in the cluster. The docked position obtained for KA-TSC and HOPNO-TSC in TySa are displayed in Figure 5. For other tyrosinases docked position are displayed in the supporting information (Figures S26-28). Even if docking studies do not give accurate values of the distances between ligand and copper atoms, we can claim that in all cases, KA-TSC or HOPNO-TSC are in interaction with copper atoms through the KA or HOPNO side. The TSC part of the molecule interacts with the second sphere coordination. However, accurate identification of the residues is illusive since the protein is fixed during docking calculations. Docked positions are in accordance with a very recent publication where X-ray structure of TRP1-Phenylthiourea (PTU) adduct demonstrated that PTU pointed outward the di-metallic center. ${ }^{[35]}$ Neither nitrogen atom (amine or thioamide groups) or sulfur atom interact with the dinuclear zinc center. However, all of these atoms are bonded with water molecules and additionally the thiourea amino group was hydrogen-bonded to a glycine residue. All these interactions contribute to stabilization and to block access to the active site. 


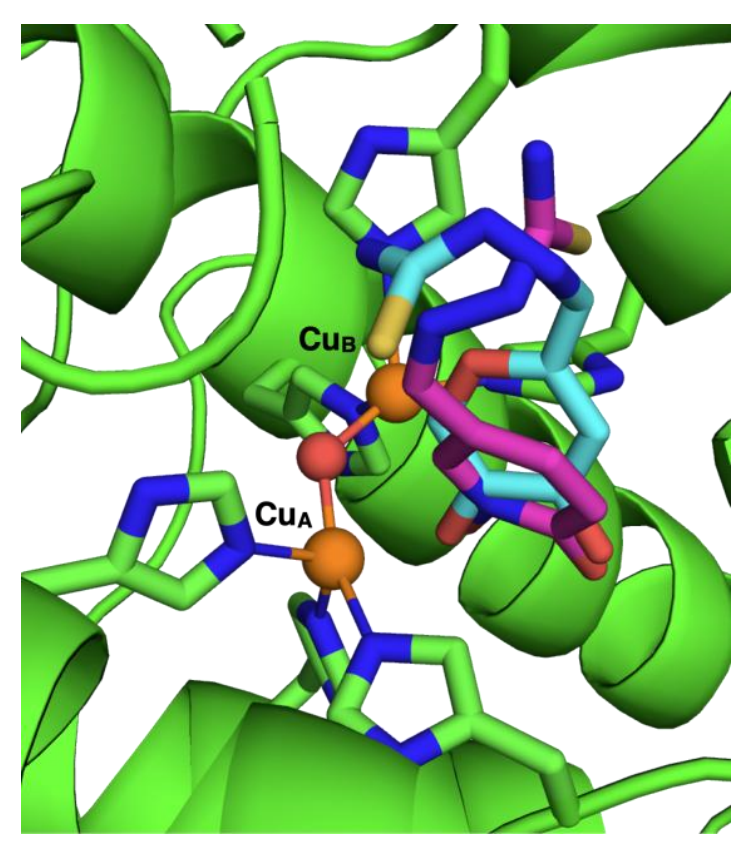

Figure 5. Dockings obtained for KA-TSC (C-atoms in light blue) and HOPNO-TSC (C-atoms in pink) in TySa (PDB code: $2 A H K)^{[3 b]}$ showing the positions of KA and HOPNO moieties in interaction with the binuclear copper center.

\section{Conclusions}

Our study shows how new efficient tyrosinase inhibitors can be designed by coupling a thiosemicarbazone moiety with a chelating motif. This approach allowed the identification of two ditopic compounds with enhanced tyrosinase inhibition properties and particularly with HOPNO-TSC for which the inhibition effects are noticeable in all isolated tyrosinases as well as on melanin synthesis in human melanoma MNT-1 cells. From model complex studies, we have successfully demonstrated the ability of KA or HOPNO moiety to chelate a dicopper center on model compound. The observed competitive (or mixed competitive) inhibition behavior, in accordance with docking studies, indicate interactions of both KA and HOPNO groups with the copper active site while the TSC group can interact with the second coordination sphere. Altogether, this study validates the approach based on chelators and represents a valuable route for the design and development of new inhibitors. resting

\section{Experimental Section}

Synthesis. General: All reagents were purchased from commercial sources and used as received. Solvents were purified by standard methods before use. The complex 4 was prepared by the method described previously. ${ }^{[32]}$ ESI mass spectra were recorded on an Esquire 300 plus Bruker Daltonis fitted with a syringe pump. UV-Vis spectra were obtained using a Cary 50 spectrophotometer operating in the 200-1000 nm range with quartz cells. The temperature was maintained at $25^{\circ} \mathrm{C}$ with a temperature control unit. ${ }^{1} \mathrm{H}$ NMR spectra were recorded on a Bruker Avance $\left({ }^{1} \mathrm{H}\right.$ at $400 \mathrm{MHz},{ }^{13} \mathrm{C}$ at $\left.100 \mathrm{MHz}\right)$ at $323 \mathrm{~K}$ with the deuterated solvent as a lock. Caution! Although no problems were encountered, suitable care and precautions should be taken when handling the perchlorate salts.

5-(dimethoxymethyl)-2-methoxy pyridine $\mathrm{N}$-oxide (1): 6-methoxy-3-pyridinecarboxaldehyde (500 $\mathrm{mg}, 3.7 \mathrm{mmol})$ was dissolved in dry methanol $(15 \mathrm{~mL})$. $p$-toluene sulfonic acid monohydrate $(160 \mathrm{mg}, 0.8 \mathrm{mmol})$ and trimethyl orthoformate $(2 \mathrm{~mL}, 18 \mathrm{mmol})$ were added, the reaction was stirred at rt and followed by TLC. When all starting material had reacted, the solvent was evaporated, saturated solution of $\mathrm{NaHCO}_{3}(40 \mathrm{~mL})$ was added to the solution and the product was extracted with $\mathrm{CH}_{2} \mathrm{Cl}_{2}(3 \times 20 \mathrm{~mL})$. The organic phase was dried with $\mathrm{MgSO}_{4}$ and the solvent was removed under reduced pressure. The crude colorless oil was dissolved in $\mathrm{CH}_{2} \mathrm{Cl}_{2}(30 \mathrm{~mL})$. $\mathrm{mCPBA}(2.55 \mathrm{~g}$, $14.8 \mathrm{mmol})$ and $\mathrm{NaHCO}_{3}(1.24 \mathrm{~g}, 14.8 \mathrm{mmol})$ were added to the solution and the reaction mixture was stirred at room temperature for 16h. The reaction mixture was filtered over Celite to remove the sticky precipitate, the solvent was removed under reduced pressure and the remaining crude solid was purified by column chromatography $\left(\mathrm{CH}_{2} \mathrm{Cl}_{2}: \mathrm{MeOH}, 95: 5\right.$ to $\left.90: 10\right)$ to give product 1 as a white solid in $41 \%$ yield $(305 \mathrm{mg}, 1.5 \mathrm{mmol}) .{ }^{1} \mathrm{H}-\mathrm{NMR}\left(400 \mathrm{MHz}, \mathrm{CDCl}_{3}\right)$ : $\delta 8.29(\mathrm{~s}, 1 \mathrm{H}),, 7.27(\mathrm{dd}, 1 \mathrm{H}, J=1.9 \mathrm{~Hz}, 8.6 \mathrm{~Hz}), 6.83(\mathrm{~d}, 1 \mathrm{H}, J=8.6 \mathrm{~Hz})$, $5.27(\mathrm{~s}, 1 \mathrm{H}), 4.00(\mathrm{~s}, 3 \mathrm{H}), 3.22(\mathrm{~s}, 3 \mathrm{H}) .{ }^{13} \mathrm{C}-\mathrm{NMR}\left(100 \mathrm{MHz}, \mathrm{CDCl}_{3}\right) \delta 158.3,139.0,129.0,126.4,107.4,99.5,57.3,52.5$. 
4-(dimethoxymethyl)-pyridine $\mathrm{N}$-oxide (3): 4-pyridinecarboxaldehyde (1g, $9.3 \mathrm{mmol}$ ) was dissolved in dry methanol (5 $\mathrm{mL})$. Trimethyl orthoformate $\left(1 \mathrm{~mL}, 9 \mathrm{mmol}\right.$ ) and $\mathrm{H}_{2} \mathrm{SO}_{4}$ (conc; $0.2 \mathrm{~mL}$ ) were added, the reaction was refluxed and followed by TLC. When all starting material had reacted, the solvent was evaporated, $\mathrm{NaHCO}_{3}(40 \mathrm{~mL})$ was added to the solution and the product was extracted with $\mathrm{CH}_{2} \mathrm{Cl}_{2}(3 \times 20 \mathrm{~mL})$. The organic phase was dried with $\mathrm{Na}_{2} \mathrm{SO}_{4}$ and the solvent was removed under reduced pressure to yield the crude product as a colorless oil. The crude colorless oil $(200 \mathrm{mg}, 1.3 \mathrm{mmol})$ was dissolved in $\mathrm{CHCl}_{3}(10 \mathrm{~mL})$. $\mathrm{mCPBA}(0.9 \mathrm{~g}, 5.2 \mathrm{mmol})$ and $\mathrm{NaHCO}_{3}(440 \mathrm{mg}, 5.2 \mathrm{mmol}$ ) were added to the solution and the reaction mixture was stirred at room temperature and followed by TLC. When all starting material had reacted, the reaction mixture was filtered over silica to remove the precipitate, the solvent was removed under reduced pressure and the remaining crude product was purified by column chromatography $\left(\mathrm{CH}_{2} \mathrm{Cl}_{2}: \mathrm{MeOH}, 95: 5\right.$ to $\left.90: 10\right)$ to yield product 3 as a white solid in $68 \%$ yield $(149 \mathrm{mg}, 0.88 \mathrm{mmol}) .{ }^{1} \mathrm{H}-\mathrm{NMR}\left(400 \mathrm{MHz}, \mathrm{CDCl}_{3}\right): \delta 8.31(\mathrm{~d}, 2 \mathrm{H}, \mathrm{J}=6.8 \mathrm{~Hz}), 7.44(\mathrm{~d}, 2 \mathrm{H}, J=$ $6.7 \mathrm{~Hz}), 5.40(\mathrm{~s}, 1 \mathrm{H}), 3.32(\mathrm{~s}, 6 \mathrm{H})$.

HOPNO-TSC: 5-(dimethoxymethyl)-2-methoxy pyridine $\mathrm{N}$-oxide $(\mathbf{1}, 120 \mathrm{mg}, 0.60 \mathrm{mmol})$ was suspended in ethanol $(5 \mathrm{~mL})$, thiosemicarbazide $(116 \mathrm{mg}, 1.27 \mathrm{mmol}$ ) was added followed by $\mathrm{HCl}$ (conc.; $0.5 \mathrm{~mL}$ ) and the temperature was increased to reflux. After $14 \mathrm{~h}$, the temperature was lowered to ambient. The formed precipitate was filtered and washed with ethanol to give HOPNO-TSC as a light brown solid in $68 \%$ yield $(86 \mathrm{mg}, 0.41 \mathrm{mmol}) .{ }^{1} \mathrm{H}-\mathrm{NMR}\left(400 \mathrm{MHz}\right.$, DMSO- $\left.\mathrm{d}_{6}\right): \delta 11.33(\mathrm{~s}, 1 \mathrm{H}), 8.36(\mathrm{~d}, 1 \mathrm{H}, J=2.3 \mathrm{~Hz}), 8.05(\mathrm{dd}, 1 \mathrm{H}$, $J=2.4,9.4 \mathrm{~Hz}$ ) 8.01 (broad d, 2H), $7.82(\mathrm{~s}, 1 \mathrm{H}), 6.54$ (d, $1 \mathrm{H}, J=9.5 \mathrm{~Hz}$ ). ${ }^{13} \mathrm{C}-\mathrm{NMR}(100 \mathrm{MHz}$, DMSO-d 6 ): $\delta 177.6,157.7,138.2,136.6$, 135.2, 119.1, 113.0 MS (ESI) $\mathrm{m} / 2211(\mathrm{M}-\mathrm{H})^{-}$Anal. Calculated for $\mathrm{C}_{7} \mathrm{H}_{8} \mathrm{~N}_{4} \mathrm{O}_{2} \mathrm{~S} \cdot 0.25 \mathrm{H}_{2} \mathrm{O}: \mathrm{C} 38.79, \mathrm{H} 3.95, \mathrm{~N} 25.85$, Found: $\mathrm{C} 38.99, \mathrm{H}$ $3.98, \mathrm{~N} 25.02$.

3-PyNO-TSC: 3-pyridinecarboxaldehyde $(1 \mathrm{~g}, 9.3 \mathrm{mmol})$ and p-toluenesulfonic acid monohydrate $(350 \mathrm{mg}, 1.8 \mathrm{mmol})$ were dissolved in methanol $(5 \mathrm{~mL})$. Trimethyl orthoformate $(1 \mathrm{~mL}, 9 \mathrm{mmol})$ was added, the reaction was refluxed and followed by TLC. When all starting material had reacted, the temperature was decreased to ambient and the solvent was evaporated. $\mathrm{NaHCO}_{3}(40 \mathrm{~mL})$ was added to the solution and the product was extracted with $\mathrm{CH}_{2} \mathrm{Cl}_{2}(3 \times 20 \mathrm{~mL})$. The organic phase was dried with $\mathrm{Na}_{2} \mathrm{SO}_{4}$ and the solvent was removed under reduced pressure to yield a yellow oil. The crude yellow oil $(200 \mathrm{mg}, 1.3 \mathrm{mmol})$ was dissolved in $\mathrm{CHCl}_{3}(10 \mathrm{~mL})$. $\mathrm{mCPBA}(900 \mathrm{mg}$, $5.2 \mathrm{mmol})$ and $\mathrm{NaHCO}_{3}(440 \mathrm{mg}, 5.2 \mathrm{mmol})$ were added to the solution and the reaction mixture was stirred at room temperature and followed by TLC $\left(\mathrm{CH}_{2} \mathrm{Cl}_{2}: \mathrm{MeOH} 10: 1\right)$. When all starting material had reacted, the reaction mixture was filtered over Celite to remove the sticky precipitate, the solvent was removed under reduced pressure and the remaining crude solid was purified by column chromatography $\left(\mathrm{CH}_{2} \mathrm{Cl}_{2}: \mathrm{MeOH}, 100: 5\right.$ to $\left.100: 10\right)$ to give the almost pure product 2 as a yellow oil $(189 \mathrm{mg}, 1.1 \mathrm{mmol})$. The crude oil was dissolved in ethanol $(5 \mathrm{~mL})$, the temperature was increased to reflux and thiosemicarbazide (100 $\mathrm{mg}, 1.1 \mathrm{mmol})$ was added followed by $\mathrm{HCl}$ (conc.; $0.5 \mathrm{~mL}$ ). After $14 \mathrm{~h}$ the temperature was lowered to ambient. The formed precipitate was filtered and washed with ethanol to yield the product in the chlorhydrate form as a pale yellow solid in $60 \%$ yield $(152 \mathrm{mg}, 0.77 \mathrm{mmol}) .{ }^{1} \mathrm{H}-\mathrm{NMR}\left(400 \mathrm{MHz}, \mathrm{d}_{6}-\mathrm{DMSO}\right): \delta$ $11.68(\mathrm{~s}, 1 \mathrm{H}), 9.01(\mathrm{~s}, 1 \mathrm{H}), 8.35-8.37(\mathrm{~m}, 3 \mathrm{H}), 7.95-7.99(\mathrm{~m}, 2 \mathrm{H}), 7.58(\mathrm{dd}, 1 \mathrm{H}, J=6.5,8.1 \mathrm{~Hz}) ;{ }^{13} \mathrm{C}-\mathrm{NMR}\left(100 \mathrm{MHz}, \mathrm{d}_{6}-\mathrm{DMSO}\right): \delta 178.7$, 139.3, 137.0, 136.7, 134.7, 128.2, $127.1 \mathrm{MS}(\mathrm{ESI}) \mathrm{m} / \mathrm{z} 195(\mathrm{M}-\mathrm{H})^{-}$and $197(\mathrm{M}+\mathrm{H})^{+}$Anal. Calculated for $\mathrm{C}_{7} \mathrm{H}_{8} \mathrm{~N}_{4} \mathrm{OS} \cdot \mathrm{HCl}$ : C 36.13, H 3.90, N 24.08, Found: C 36.79, H 4.07, N 24.58.

4-PyNO-TSC: 4-(dimethoxymethyl)-pyridine $\mathrm{N}$-oxide $(3,149 \mathrm{mg}, 0.88 \mathrm{mmol})$ was dissolved in ethanol $(5 \mathrm{~mL})$ and thiosemicarbazide $(80$ $\mathrm{mg}, 0.88 \mathrm{mmol}$ ) was added. The temperature was increased to reflux and $\mathrm{HCl}(0.5 \mathrm{~mL})$ was added. After $14 \mathrm{~h}$, the temperature was lowered to ambient. The formed precipitate was filtered and washed with ethanol to give 4-PyNO-TSC in the chlorhydrate form as a pale yellow solid in $78 \%$ yield (134 mg, $0.68 \mathrm{mmol}) .{ }^{1} \mathrm{H}-\mathrm{NMR}\left(400 \mathrm{MHz}\right.$ DMSO- $\left.\mathrm{d}_{6}\right): \delta 11.72(\mathrm{~s}, 1 \mathrm{H}), 8.43(\mathrm{~d}, 2 \mathrm{H}, J=7.0 \mathrm{~Hz}), 8.39(\mathrm{bs}, 1 \mathrm{H})$, 8.37 (bs, 1H), $8.02\left(\mathrm{~d}, 2 \mathrm{H}, J=7.5 \mathrm{~Hz}\right.$ ), $8.01(\mathrm{~s}, 1 \mathrm{H}) .{ }^{13} \mathrm{C}-\mathrm{NMR}\left(125 \mathrm{MHz}, \mathrm{d}_{6}\right.$-DMSO) $\delta 178.9,139.9,139.2,137.3,125.1 \mathrm{MS}(\mathrm{ESI}) \mathrm{m} / \mathrm{z}$ $195(\mathrm{M}-\mathrm{H})^{-}$and $197(\mathrm{M}+\mathrm{H})^{+}$. Anal. Calculated for $\mathrm{C}_{7} \mathrm{H}_{8} \mathrm{~N}_{4} \mathrm{OS} \cdot \mathrm{HCl}$ : C 36.13, H 3.90, N 24.08, Found: C 36.84, H 4.03, N 24.70.

Synthesis of $\left[\left(\mathrm{Cu}_{2}(\mathrm{BPMP})\right)_{2}(\mathrm{KA}-\mathrm{TSC})\right]\left(\mathrm{CF}_{3} \mathrm{SO}_{3}\right)_{4}$-Solvate (5). To a heated solution of KA-TSC $(4.9 \mathrm{mg}, 23 \mu \mathrm{mol}, 3.8$ eq.) in methanol $(3.5 \mathrm{ml})$ was added the triflate salt of complex $4^{[32]}(5.8 \mathrm{mg}, 6.0 \mu \mathrm{mol}, 1$ eq.). After refluxing for $30 \mathrm{~min}$, the temperature was lowered to $\mathrm{rt}$ and the solution was filtered to remove solid particles. A slow diethyl ether diffusion of the solution lead to crystallization after one week. The brown crystals were collected from the batch and washed with diethyl ether. Elemental analysis calcd (\%) for $\left(\mathrm{C}_{73} \mathrm{H}_{71} \mathrm{Cu}_{4} \mathrm{~N}_{15} \mathrm{O}_{5} \mathrm{~S}\right)$ $\left(\mathrm{CF}_{3} \mathrm{O}_{3} \mathrm{~S}\right)_{4} \cdot 15 \mathrm{H}_{2} \mathrm{O} \cdot \mathrm{CH}_{3} \mathrm{OH}: \mathrm{C} 38.66, \mathrm{H} 3.37, \mathrm{~N} 8.67$; found: C 38.76, H 3.18, N 8.60; UV/Vis in HEPES pH 7.0 50mM, DMSO 5\%: $\lambda_{\max }(\varepsilon)$ $=390$ (1380), $650 \mathrm{~nm}\left(180 \mathrm{M}^{-1} \mathrm{~cm}^{-1}\right) ; \mathrm{ESI}-\mathrm{MS} \mathrm{m} / \mathrm{z}: \mathrm{z}=1,1016\left[M-\mathrm{H}^{+}-\mathrm{OTf}\right] ; \mathrm{z}=2,433\left[M+\mathrm{H}^{+}-2 \mathrm{OTf}\right]$ with $M=\mathrm{C}_{40} \mathrm{H}_{39} \mathrm{~N}_{9} \mathrm{Cu}_{2} \mathrm{O}_{7} \mathrm{~S}$

Crystal Structure Determination and Refinement for complex 5. Measurements were made on a Bruker-Nonius Kappa CCD diffractometer with graphite monochromatized $\mathrm{Mo}(\mathrm{K} \alpha)$ radiation $(\lambda=0.71073 \AA)$ at $200 \mathrm{~K}$. A brown block $\left(0.22 \times 0.21 \times 0.16 \mathrm{~mm}^{3}\right)$ was mounted in a nylon loop with cryoprotectant, the unit cell contains two two crystallographically independent entities. Formula: 2( $\left(\mathrm{C}_{73} \mathrm{H}_{71} \mathrm{Cu}_{4} \mathrm{~N}_{15} \mathrm{O}_{5} \mathrm{~S}\right), 8\left(\mathrm{CF}_{3} \mathrm{O}_{3} \mathrm{~S}\right), 3.33\left(\mathrm{CH}_{4} \mathrm{O}\right), 2.07\left(\mathrm{C}_{4} \mathrm{H}_{10} \mathrm{O}\right), 2.33\left(\mathrm{H}_{2} \mathrm{O}\right), M_{1}=4543.91$, triclinic, space group $P-1, a=19.634(4) \AA, b=$ 22.479(5) $\AA, c=25.062(5) \AA, \alpha=104.83(3)^{\circ}, \beta=109.46(3)^{\circ}, \gamma=94.89(3)^{\circ}, V=9905(3) \AA^{3}, Z=2, \rho_{\text {calcd }}=1.524 \mathrm{~g} \mathrm{~cm}^{-3}, \mu=1.049 \mathrm{~mm}^{-1}$, number of measured and independent reflections: 134717 and 34381, number of reflections with $I>2 \sigma(l): 23467$, Rint $=0.0550, R=$ $0.0653, w R=0.1595$, Goodness of fit $S=1.132$, refinement based on $F$ where $w=1 /\left[\sigma^{2}(F o)^{2}+(0.0501 p)^{2}+57.0103 p\right]$ with $p=\left(F_{0}^{2}+\right.$ $\left.2 \mathrm{Fo}^{2}\right) / 3$. Crystallographic structure was solved using direct methods implemented by ShelxS-97. ${ }^{[36]}$ Refinement was performed using ShelxL-2013 run under Olex2. ${ }^{[37]} \mathrm{C}, \mathrm{N}, \mathrm{O}, \mathrm{S}, \mathrm{F}$, and $\mathrm{Cu}$ atoms were refined anisotropically by the full matrix least-squares method. $\mathrm{H}$ atoms were calculated on idealized positions and constrained on their bearing atoms. CCDC 1411880 contains the full data collection parameters and structural data for 5 .

Enzymatic Assays: The A. bisporus Ty (EC 1.14.18.1) used for the bioassay was purchased from Sigma (St. Louis, MO, USA) as a mixture of different polyphenol oxidases. A. bisporus Ty was dissolved in $50 \mathrm{mM}$ phosphate buffer $(5 \mathrm{~mL}, \mathrm{pH} 7.0)$ and purified on Qsepharose FF chromatography by a gradient of $\mathrm{NaCl}$ from 0 to $1.0 \mathrm{M} \cdot{ }^{[38]}$ Purity of tyrosinase was checked with SDS-PAGE gel (Figure $\mathrm{S} 3$ ); the purified tyrosinase exhibits only two bands at $\mathrm{M}$. W. = ca. $14 \mathrm{kDa}$ ( $\mathrm{L}$ subunit) and $45 \mathrm{kD}$ (H subunit). Only the heavy (H) subunit displays the dicopper center ${ }^{[2 a]}$ and possesses activity. ${ }^{[39]}$ The tyrosinase activity was checked with spectroscopic method using L-DOPA as substrate. S. antibioticus Ty was prepared from liquid cultures of $S$. antibioticus harboring the plJ703 expression plasmid, and purified according to published procedures. ${ }^{[2]}$ Through all purification steps, protein solutions were kept on ice to prevent loss of enzymatic 
activity. The purity of the sample was indicated by the presence of a single band in the SDS-PAGE gel (Figure S3). Human tyrosinase was produced and purified as previously described. ${ }^{[21 c]}$ and the corresponding SDS-PAGE gel is shown on Figure S4.

Ty diphenolase activity was spectrophotometrically monitored at $25^{\circ} \mathrm{C}$ by following the formation of dopachrome at a wavelength of 475 $\mathrm{nm}\left(\varepsilon=3,400 \mathrm{M}^{-1} \cdot \mathrm{cm}^{-1}\right) \cdot{ }^{[40]}$ L-DOPA was dissolved in phosphate buffer $100 \mathrm{mM}, \mathrm{pH} 7.2$.

Typical assay on A. bisporus and S. antibioticus Ty. A microplate was charged with inhibitor and L-DOPA (0.078 to $10 \mathrm{mM})$ or L-DOPA alone in phosphate buffer ( $50 \mathrm{mM}$ with $2 \% \mathrm{DMSO}$ ). The enzyme was added to the mixture to initiate the reaction and the enzyme reaction was monitored by measuring the change in absorbance at $475 \mathrm{~nm}^{[40]}$ of the DOPAchrome for $3 \mathrm{~min}$ at $25^{\circ} \mathrm{C}$.

Typical assay on human tyrosinase. Inhibitors were dissolved in DMSO (final concentration of DMSO in the reaction mixture was $2 \%$ ). The concentrations of L-DOPA employed ranged from $0.096 \mathrm{mM}$ to $9.6 \mathrm{mM}$, and the concentrations of inhibitors tested ranged from 0.01 to $0.85 \mathrm{mM}$. The kinetic constants were determined in a 96-well plate assay, using a SpectraMax 190 Absorbance Microplate Reader equipped with SoftMax 4.8 software or using a single $100 \mu \mathrm{L}$ quartz cell and the Agilent 8453 UV-visible Spectroscopy System.

The $K_{\mathrm{M}}$ and $V_{\max }$ values were calculated by fitting the obtained initial velocity $\left(v_{0}\right)$ to the Michaelis-Menten equation, (Figures S5-20) using the Kaleidagraph software. The type of inhibitory mechanism against Ty during the oxidation of L-DOPA was determined by fitting the $v_{0}$ values obtained at different substrates and inhibitor concentrations to the equations describing different modes of inhibition, using the Kaleidagraph software. All measurements were done in triplicate, and the reported values are the mean and the standard error of at least three independent experiments.

Tests on MNT-1 cells. Human melanoma cells (MNT-1) ${ }^{[41]}$ were obtained from the National Institute of Health (NIH) and were grown in Dulbecco's Modified Eagle Medium (DMEM) supplemented with $10 \%$ fetal calf serum and $1 \%$ antibiotics, in $75 \mathrm{~cm}^{3}$ ventilated flask maintained at $37^{\circ} \mathrm{C}$ in a $5 \% \mathrm{CO}_{2}$ incubator. Cells were routinely passed using trypsin-EDTA solution. Inhibition of tyrosinase by HOPNOTSC, KA-TSC, HOPNO and KA compounds on MNT-1 was evaluated using cell lysate prepared from MNT-1 cells. Briefly, confluent MNT-1 cells cultivated on $75 \mathrm{~cm}^{3}$ flasks were washed with phosphate buffer saline (PBS) and detached using trypsin-EDTA solution. Cells suspension was aliquoted in cryotubes (approximately $4.10^{\mathrm{E} 6}$ cells per tube) and tubes were then centrifuged at 1,200 rpm for 5 min. Supernatants were eliminated and cells pellets were snap-frozen in liquid nitrogen before being stored at $-80^{\circ} \mathrm{C}$ until tyrosinase assay. The day of the assay, tubes containing cell pellets were defrosted and cells were resuspended in $1.5 \mathrm{~mL}$ of PBS containing $0.1 \%$ Triton $\mathrm{X}-100$. Tubes were incubated in ice during $10 \mathrm{~min}$ before being centrifuged at 1,200 rpm for 5 min. Supernatants corresponding to MNT1 cell extract were collected and used for tyrosinase assay. Cell extracts were first diluted to $10 \mathrm{~mL}$ with PBS and then added to 96 -wells plate (100 $\mu \mathrm{L}$ per well). $10 \mu \mathrm{L}$ of test compounds (diluted in DMSO) were next added to the wells and were serially diluted 2-times directly into the 96 -wells plate. Finally, $100 \mu \mathrm{L}$ of a L-DOPA solution (initial concentration of $4 \mathrm{mM}$ ) were added in each well and the OD at $600 \mathrm{~nm}$ was immediately recorded ( $\mathrm{t}_{0}$ measurement). Plates were then incubated at $37^{\circ} \mathrm{C}, \mathrm{OD}$ at $600 \mathrm{~nm}$ being continuously recorded until it reached $O D \approx 0.5$ (about $t_{f}=t_{0}+3$ hours). Variation of $O D_{600 n m}$ was calculated $\left(O D_{t f}-O D_{t 0}\right)$ and used to determine $I C_{50}$

Computational methods. DFT calculations were done on model complex using the Gaussian09 package ${ }^{[42]}$. Full geometry optimizations were carried out for all systems using the hybrid functional B3LYP and the $6-31 \mathrm{~g}^{*}$ basis set on all atoms. Vibrational frequency calculations were performed to ensure that each geometry optimization converged to a real minimum. Energetic analysis was carried out from additional single point high-spin and broken-symmetry calculations on the previously optimized geometries. For that purpose, the B3LYP functional was used together with a general basis set $\left(6-311 \mathrm{G}^{\star}\right.$ for $\mathrm{Cu}$ and coordinating $\mathrm{O}$ atoms, and $6-31 \mathrm{G}^{\star}$ for all remaining atoms)

Docking calculations were done using the Autodock 4.0 software ${ }^{[34]}$. The input files for docking calculations were prepared with ADT Tools using Gasteiger partial charges for both enzymes and hybrid compounds. A grid of $60 \times 60 \times 60$ points centered on the active site and separated by $0.2 \AA$ was used for the docking. A conformational search was performed using a genetic algorithm with an initial population of 50 randomly placed individuals, a maximum number of $2.5 \times 10^{5}$ energy evaluations, a maximum number of $2.7 \times 10^{4}$ generations, a mutation rate of 0.02 , and a crossover rate of 0.8 . 100 conformers of the ligand were generated. Results less than $2.0 \AA$ in positional root-mean-square deviation (RMSD) were clustered together.

For the choice of the enzyme structures, since the protein is fixed during our docking calculations, it is best to work on resolved structures with inhibitors. For the fungal tyrosinase, we used the crystallographic tyrosinase from Agaricus bisporus with the inhibitor tropolone (PDB code: $2 \mathrm{Y9X})^{[2 \mathrm{a}]}$. In the absence of an X-ray structure of Streptomyces antibioticus, the docking studies were performed by using crystallographic data for Streptomyces castaneoglobisporus (PDB code: $2 \mathrm{AHK}{ }^{[3 \mathrm{~b}]}$ which sharing $82 \%$ identity to Streptomyces antibioticus as previously reported. ${ }^{[27]}$ This tyrosinase is complexed with a caddie protein with a tyrosine residue in to the active site. Finally for the human Tyrosinase, we used the homology model published before. ${ }^{[4]}$ Since we studied the inhibition properties of chelating compounds in presence of L-Dopa for all tyrosinase sources studied herein, the reference structure to investigate the docking of inhibitors into the active site could be the met or the oxy form. As the crystallographic structure of $2 \mathrm{AHK}$ is the met form, we choose to work on this form for all tyrosinases. However, since recently new crystallographic structures of the oxy forms of the fungal Agaricus oryzae Tyrosinase ${ }^{[44]}$ were obtained showing an important rearrangement of the active site upon binding L-tyrosine (PDB codes: $6 \mathrm{JUC}$ and 6JUA respectively with and without this rearrangement) additional calculations on these forms were performed and results are given in Supporting Information (Figures S27-S28).

\section{Acknowledgements}


The authors gratefully acknowledge the Labex Arcane (ANR-11-LABX-0003-01) with a grant for EB and Cosmethics an "Investissements d'Avenir" program (ANR-15-IDEX-02) with a grant for CF. The authors are grateful to ICMG FR 2607 (PCN-ICMG) for the analytical facilities (NMR, ESI-MS and RX) and to CECIC for computing facilities. This work has been partially supported by the CBH-EUR-GS (ANR-17-EURE-003) program, in the framework of which this work was carried out, and by the Progetto di Ricerca di Ateneo (CPDA110789/11) from the University of Padova.

Keywords: bio-inorganic chemistry $\bullet$ copper active site $\bullet$ tyrosinase $\bullet$ ditopic inhibitors $\bullet$ docking $\bullet$

\section{References:}

[1] a) E. I. Solomon, D. E. Heppner, E. M. Johnston, J. W. Ginsbach, J. Cirera, M. Quyyum, M. T. Kieber-Emmons, C. H. Kjaergaard, R. G. Hadt, L. Tian, Chem. Rev. 2014, 114, 3659; b) A. Bijelic, A. Rompel, C. Belle, in Bioinspired Chemistry: From Enzymes to Synthetic Models, Vol. 5 (Ed.: M. Réglier), World Scientific., 2019, pp. 155.

[2] a) W. T. Ismaya, H. J. Rozeboom, A. Weijn, J. J. Mes, F. Fusetti, H. J. Wichers, B. W. Dijkstra, Biochemistry 2011, 50, 5477; b) S. Fujieda, S. Yabuta, T. Ikeda, T. Oyama, N. Muraki, G. Kurisu, S. Itoh, J. Biol. Chem. 2013, 288, 22128; c) S. G. Mauracher, C. Molitor, R. Al-Oweini, U. Kortz, A. Rompel, Acta Crystallogr. Sect. 2014, 70, 2301.

[3] a) M. Sendovski, M. Kanteev, V. Shuster Ben-Yosef, N. Adir, A. Fishman, J. Mol. Biol. 2011, 405, 227; b) Y. Matoba, T. Kumagai, A. Yamamoto, H. Yoshitsu, M. Sugiyama, J. Biol. Chem. 2006, 281, 8981.

[4] Y. Li, Y. Wang, H. Jiang, J. Deng, PNAS 2009, 106, 17002.

[5] a) T. Masuda, K. Momoji, T. Hirata, B. Mikami, FEBS J. 2014, 281, 2659; b) A. Bijelic, M. Pretzler, C. Molitor, F. Zekiri, A. Rompel, Angew. Chem. Int. Ed Engl. 2015, 54, 14677.

[6] B. Lai, H. J. Wichers, M. Soler-Lopez, B. W. Dijkstra, Angew. Chem. Int. Ed Engl. 2017, 56, 9812.

[7] a) H. Decker, F. Tuczek, Angew. Chem. Int. Ed Engl. 2017, 56, 14352 ; b) B. Lai, H. J. Wichers, M. Soler-Lopez, B. W. Dijkstra, Chem. Eur. J. 2018, 24, 47.

[8] a) M. Rolff, J. Schottenheim, H. Decker, F. Tuczek, Chem. Soc. Rev. 2011, 40, 4077; b) A. W. J. W. Tepper, E. Lonardi, L. Bubacco, G. W. Canters, in Handbook of metalloproteins, Vol. 5 (Ed.: Messerschmidt), Albrecht, 2011, pp. 571; c) C. A. Ramsden, P. A. Riley, Biorg. Med. Chem. 2014, 22, 2388; d) J. N. Rodríguez-López, J. Tudela, R. Varón, F. García-Carmona, F. García-Cánovas, J. Biol. Chem. 1992, 267, 3801; e) A. Sanchez-Ferrer, J. N. Rodrigez-Lopez, F. García-Cánovas, F. Garcia-Carmona, Biochim. Biophys. Acta 1995, $1247,1$.

[9] a) A. M. Mayer, Phytochemistry 2006, 67, 2318; b) M. R. Loizzo, R. Tundis, R. Menichini, Compr. Rev. Food Sci. Food Saf. 2012, 11, 378; c) M. Friedman, J. Agri. Food Chem. 1996, 44, 631.

[10] a) T. S. Chang, Int. J. Mol. Sci. 2009, 10, 2440; b) W. A. Fisk, O. Agbai, H. A. Lev-Tov, R. K. Sivamani, J. Am. Acad. Dermatol. 2014, 70 , 352; c) E. Mendes, M. de Jesus Perry, A. P. Francisco, Expert Opin. Drug Discov.. 2014, 9, 533.

[11] M. Yaar, J. Invest. Dermatol. 2013, 133, 11.

[12] a) V. N. Sehgal, G. Srivastava, Int. J. Dermatol. 2008, 47, 1041; b) A. Y. Chen, R. N. Adamek, B. L. Dick, C. V. Credille, C. N. Morrison, S. M. Cohen, Chem. Rev. 2019, 119, 1323; c) B. Roulier, B. Pérès, R. Haudecoeur, J. Med. Chem. 2020, 63, 13428.

[13] a) J. Segura-Aquilar, I. Paris, P. Munoz, E. Ferrari, L. Zecca, F. A. Zucca, J. Neurochem. 2014, 129, 898; b) E. Greggio, E. Bergantino, D. Carter, R. Ahmad, G.-E. Costin, V. J. Hearing, J. Clarimon, A. Singleton, J. Eerola, O. Hellström, P. J. Tienari, D. W. Miller, A. Beilina, L. Bubacco, M. R. Cookson, J. Neurochem. 2005, 93, 246.

[14] E. Buitrago, R. Hardré, R. Haudecoeur, H. Jamet, C. Belle, A. Boumendjel, L. Bubacco, M. Réglier, Curr. Top. Med. Chem 2016, 16, 3033.

[15] T. Pillaiyar, M. Manickam, V. Namasivayam, J. Enzyme Inhib. Med. Chem. 2017, 32, 403.

[16] a) G.-K. Agnieszka, P. Justyna, M. Henryk, Curr. Med. Chem. 2016, 23, 3548; b) S. Y. Lee, N. Baek, T.-g. Nam, J. Enzyme Inhib. Med. Chem. 2016, 31, 1; c) C.-Y. Chen, L.-C. Lin, W.-F. Yang, J. Bordon, H.-M. D. Wang, Curr. Org. Chem. 2015, 19, 4; d) T. Pillaiyar, V. Namasivayam, M. Manickam, S.-H. Jung, J. Med.Chem. 2018, 61, 7395; e) S. Zolghadri, A. Bahrami, M. T. Hassan Khan, J. MunozMunoz, F. Garcia-Molina, F. Garcia-Canovas, A. A. Saboury, J. Enzyme Inhib. Med. Chem. 2019, 34, 279.

[17] E. Buitrago, A. Vuillamy, A. Boumendjel, W. Yi, G. Gellon, R. Hardré, C. Philouze, G. Serratrice, H. Jamet, M. Réglier, C. Belle, Inorg. Chem. 2014, 53, 12848.

[18] E. Peyroux, W. Ghattas, R. Hardré, M. Giorgi, B. Faure, A. J. Simaan, C. Belle, M. Réglier, Inorg. Chem. 2009, 48, 10874.

[19] a) J. M. Noh, S.-Y. Kwak, H.-S. Seo, J.-H. Seo, B.-G. Kim, Y.-S. Lee, Bioorg. Med. Chem. Lett. 2009, 19, 5586; b) D.-F. Li, P.-P. Hu, M.-S. Liu, X.-L. Kong, J.-C. Zhang, R. C. Hider, T. Zhou, J. Agric. Food Chem. 2013, 61, 6597; c) S. M. Hashemi, E. S., Pharm. Biomed. Res. 2015, 1, 1; d) M. J. Chen, C. C. Hung, Y. R. Chen, S. T. Lai, C. F. Chan, J. Biosci. Bioeng. 2016, 122, 666; e) W. Xie, H. Zhang, J. He, J. Zhang, Q. Yu, C. Luo, S. Li, Bioorg. Med. Chem. Lett. 2017, 27, 530; f) L. Saghaie, M. Pourfarzam, A. Fassihi, B. Sartippour, Res. Pharm. Sci. 2013, 8, 233; g) A. Asadzadeh, H. Sirous, M. Pourfarzam, P. Yaghmaei, A. Fassihi, Iran Basic Med. Sci. 2016, 19, 132.

[20] W. Yi, C. Dubois, S. Yahiaoui, R. Haudecoeur, C. Belle, H. Song, R. Hardré, M. Réglier, A. Boumendjel, Eur. J. Med. Chem. 2011, 46, 4330.

[21] a) J. S. Chen, C. Wei, M. R. Marshall, J. Agri. Food Chem. 1991, 39, 1897; b) R. C. Hider, K. Lerch, Biochem. J. 1989, 257, 289 ; c) S. Fogal, M. Carotti, L. Giaretta, F. Lanciai, L. Nogara, L. Bubacco, E. Bergantino, Mol. Biotechnol. 2015, 57, 45; d) B. Deri, M. Kanteev, M. Goldfeder, D. Lecina, V. Guallar, N. Adir, A. Fishman, Sci. Rep. 2016, 6, 34993.

[22] L. Bubacco, M. van Gastel, E. J. J. Groenen, E. Vijgenboom, G. W. Canters, J. Biol. Chem. 2003, 278, 7381.

[23] L. Bubacco, R. Spinazze, S. della Longa, M. Benfatto, Arch. Biochem. Biophys. 2007, $278,320$.

[24] L. Bubacco, E. Vijgenboom, C. Gobin, A. W. J. W. Tepper, J. Salgado, G. W. Canters, J. Mol. Catal. B:Enzym. 2000, 8, 27.

[25] C. R. Lima, J. R. A. Silva, É. De Tássia Carvalho Cardoso, E. O. Silva, J. Lameira, J. L. Do Nascimento, D. Do Socorro Barros Brasil, C. N. Alves, Molecules 2014, 19.

[26] C. Bochot, A. Gouron, L. Bubacco, A. Milet, C. Philouze, M. Réglier, G. Serratrice, H. Jamet, C. Belle, Chem. Commun. 2014, 50, 308. 
[27] R. Haudecoeur, A. Gouron, A. Dubois, H. Jamet, M. Lightbody, R. Hardré, A. Milet, E. Bergantino, L. Bubacco, C. Belle, M. Réglier, A. Boumendjel, ChemBioChem. 2014, 15, 1325 .

[28] a) T. F. M. Kuijpers, T. van Herk, J.-P. Vincken, R. H. Janssen, D. L. Narth, W. J. H. van Berkel, H. Gruppen, J. Agric. Food Chem. 2014, 62, 214; b) E. Selinheimo, D. NiEidhin, C. Steffensen, J. Nielsen, A. Lomascolo, S. Halaouli, E. Record, D. O'Beirne, J. Buchert, K. Kruus, J. Biotech. 2007, 130, 471.

[29] C. Bochot, E. Favre, C. Dubois, B. Baptiste, L. Bubacco, P.-A. Carrupt, G. Gellon, R. Hardré, D. Luneau, Y. Moreau, A. Nurisso, M. Réglier, G. Serratrice, C. Belle, H. Jamet, Chem. Eur. J. 2013, 19, 3655.

[30] U. Ghani, N. Ullah, Biorg. Med. Chem. 2010, 18, 4042.

[31] R. Haudecoeur, M. Carotti, A. Gouron, M. Maresca, E. Buitrago, R. Hardré, E. Bergantino, H. Jamet, C. Belle, M. Réglier, L. Bubacco, A. Boumendjel, ACS Med. Chem. Let. 2017, 8, 55.

[32] S. Torelli, C. Belle, I. Gautier Luneau, J. L. Pierre, E. Saint Aman, J. M. Latour, L. Le Pape, D. Luneau, Inorg. Chem. 2000, 39, 3526.

[33] a) H. Gampp, M. Maeder, C. J. Meyer, A. D. Zuberbühler, Talanta 1985, 32, 95; b) H. Gampp, M. Maeder, C. J. Meyer, A. D. Zuberbühler, Talanta 1985, 32, 257; c) H. Gampp, M. Maeder, C. J. Meyer, A. D. Zuberbühler, Talanta 1986, 33, 943.

[34] G. M. Morris, D. S. Goodsell, R. S. Halliday, R. Huey, W. E. Hart, R. K. Belew, A. J. Olson, J. Comput. Chem. 1998, $19,1639$.

[35] X. Lai, H. J. Wichers, M. Soler-López, B. W. Dijkstra, Int. J. Mol. Sci. 2020, 21, 915.

[36] G. M. Sheldrick, Acta Cryst. 2008, A64, 112

[37] O. V. Dolomanov, L. J. Bourhis, R. J. Gildea, J. A. K. Howard, H. Puschmann, J. Appl. Cryst. 2009, 42, 339.

[38] S. Yamazaki, S. Itoh, J. Am. Chem. Soc. 2003, 125, 13034

[39] W. T. Ismaya, H. J. Rozeboom, H. J. Schuring, C. G. Boeriu, H. J. Wichers, B. W. Dijkstra, Acta Crystallogr. 2011, F67, 575.

[40] H. S. Mason, J. Biol. Chem. 1948, 172, 83.

[41] K. G. Chen, R. D. Leapman, G. Zhang, B. Lai, J. C. Valencia, C. O. Cardarelli, W. D. Vieira, V. J. Hearing, M. M. Gottesman, J. Natl. Cancer Inst. 2009, 101, 1259.

[42] G. W. T. M. J. Frisch, H. B. Schlegel, G. E. Scuseria, M. A. Robb, J. R. Cheeseman, G. Scalmani, V. Barone, B. Mennucci, G. A. Petersson, H. Nakatsuji, M. Caricato, X. Li, H. P. Hratchian, A. F. Izmaylov, J. Bloino, G. Zheng, J. L. Sonnenberg, M. Hada, M. Ehara, K. Toyota, R. Fukuda, J. Hasegawa, M. Ishida, T. Nakajima, Y. Honda, O. Kitao, H. Nakai, T. Vreven, J. A. Montgomery, Jr., J. E. Peralta, F. Ogliaro, M. Bearpark, J. J. Heyd, E. Brothers, K. N. Kudin, V. N. Staroverov, R. Kobayashi, J. Normand, K. Raghavachari, A. Rendell, J. C. Burant, S. S. lyengar, J. Tomasi, M. Cossi, N. Rega, J. M. Millam, M. Klene, J. E. Knox, J. B. Cross, V. Bakken, C. Adamo, J. Jaramillo, R. Gomperts, R. E. Stratmann, O. Yazyev, A. J. Austin, R. Cammi, C. Pomelli, J. W. Ochterski, R. L. Martin, K. Morokuma, V. G. Zakrzewski, G. A. Voth, P. Salvador, J. J. Dannenberg, S. Dapprich, A. D. Daniels, A. Farkas, J. B. Foresman, J. V. Ortiz, J. Cioslowski, and D. J. Fox, , Revision D01 ed. (Ed.: I. Gaussian, Wallingford CT), 2009.

[43] E. Favre, A. Daina, P.-A. Carrupt, A. Nurisso, Chem. Biol. Drug Des. 2014, 84, 206.

[44] N. Fujieda, K. Umakoshi, Y. Ochi, Y. Nishikawa, S. Yanagisawa, M. Kubo, G. Kurisu, S. Itoh, Angew. Chem. Int. Ed. 2020, $59,13385$. 